UMBARA

Indonesian Journal of Anthropology

Volume 5 (1) Juli 2020 || eISSN 2528-1569 | pISSN 2528-2115 || http://jurnal.unpad.ac.id/umbara

DOI : $10.24198 /$ umbara.v5i1.28187

\title{
Perilaku dan Peran Tokoh Masyarakat dalam Pencegahan dan Penanggulangan Pandemi Covid -19 di Desa Jayaraga, Kabupaten Garut
}

\author{
Udin Rosidin $^{1}$, Laili Rahayuwati², Erna Herawati ${ }^{3}$ \\ ${ }^{1}$ Fakultas Keperawatan, Universitas Padjadjaran \\ udin.rosidin@unpad.ac.id \\ ${ }^{2}$ Fakultas Keperawatan, Universitas Padjadjaran \\ laili.rahayuwati@unpad.ac.id \\ ${ }^{3}$ Departemen Antropologi, FISIP, Universitas Padjadjaran \\ e.herawati@unpad.ac.id
}

\begin{abstract}
This study aims to describe behaviour and roles of community leaders in the Covid-19 prevention at Jayaraga Village, Garut District. This study applied qualitative method. Data were collected through discussion with community leaders who joined whatsapp group. This study reveals that the behaviour of community leaders is the product of their knowledge and attitude. They have sufficient knowledge about Covid-19 which in turns construct their attitude towards it. They worry about the disease its rapid contagion and its negative impact to the community. Having this attitude, they decided to start actions for prevention, and invited community members to join them in the action. They promoted healthy life behaviour, which is known effective in prevent the Covid-19 contagion, and initiated actions which aims to assist members of the community whose socio-economic condition devastated by the pandemic. The behaviour of these community leaders describes their roles in the community in the context of Covid-19 pandemic. This behaviour also enhances empowerment of the to Covid-19 pandemic.
\end{abstract}

Keywords: behaviour, roles, public figure, Covid-19

\begin{abstract}
Abstrak
Penelitian ini menggambarkan perilaku dan peran tokoh masyarakat dalam upaya pencegahan dan penanggulangan pandemi Covid-19 Desa Jayaraga, di Kabupaten Garut. Penelitian ini menggunakan metode kualitatif deskriptif eksploratoris. Teknik pengumpulan data dilakukan melalui diskusi di grup media sosial Whatsapp. Hasil penelitian menggambarkan bahwa perilaku para tokoh masyarakat merupakan produk dari pengetahuan dan sikap mereka pada Covid-19. Mereka memiliki perilaku yang proaktif dalam upaya merespon pandemi. Para tokoh masyarakat memiliki pengetahuan tentang Covid-19 yang memadai. Pengetahuan itu menumbuhkan sikap khawatir mereka pada cepatnya penyebaran virus dan dampaknya. Sikap itu mendorong mereka bertindak mengajak warga masyarakat untuk melakukan upaya pencegahan dan penanggulangan dampak pandemi. Mereka tidak hanya mengajak dan menghimbau tetapi sekaligus memberi contoh tindakan pencegahan melalui penerapan tindakan perilaku hidup bersih dan sehat; serta memotori kegiatan
\end{abstract}


memberikan bantuan pada warga yang kondisi sosial-ekonominya terdampak pandemi. Perilaku para tokoh masyarakat itu sekaligus menggambarkan peran mereka dalam upaya pencegahan dan penanggulangan pandemi; yang sekaligus juga mendorong tumbuhnya kemandirian warga masyarakat desa di dalam merespon pandemi Covid-19.

Kata kunci: perilaku, peran, tokoh masyarakat, Covid-19

\section{Pendahuluan}

Pandemi Covid-19 melanda Indonesia sejak Maret 2020. Upaya mencegah penyebaran virus dan menanggulangi dampak pandemi bukan hanya merupakan tanggung jawab pemerintah semata, tetapi memerlukan peran serta setiap elemen masyarakat. Apabila setiap warga masyarakat berperan aktif dalam upaya pencegahan, maka pandemi akan berhasil dikendalikan. Para ahli kesehatan menganjurkan penggunaan masker, menjaga jarak saat interaksi sosial, dan rajin mencuci tangan dengan sabun dan air bersih yang mengalir sebagai kunci utama memutus mata rantai penyebaran virus. Hal ini tampak mudah, tetapi pada dasarnya sulit diterapkan secara konsisten di masyarakat karena merupakan sebuah tindakan yang relatif baru dan belum menjadi kebiasaan apalagi perilaku di masyarakat. Pengenalan tindakan baru menjadi kebiasaan dan bahkan menjadi perilaku yang memerlukan waktu dan memerlukan promosi secara berulang-ulang. Padahal, mencuci tangan dengan air bersih dan sabun merupakan salah satu dari aneka indikator perilaku hidup bersih dan sehat (PHBS) yang telah diperkenalkan dan dipromosikan oleh pemerintah sejak 2016.

Perilaku Hidup Bersih dan Sehat (PHBS), merujuk pada perilaku yang dilakukan oleh individu atas kesadaran sendiri, agar dapat menolong dirinya sendiri di bidang kesehatan dan berperan aktif dalam kegiatan-kegiatan kesehatan (Kementerian Kesehatan, 2016). Himbauan PHBS bahkan telah ditetapkan melalui Peraturan Menteri Kesehatan Republik Indonesia Nomor: 2269/MENKES/PER/XI/2011. Sebagai pendukung pelaksanaan peraturan ini, Kementerian Kesehatan juga mencanangkan Gerakan Masyarakat Sehat (Germas) di Indonesia sejak 15 November 2016 (Primadi, 2017). Germas merupakan upaya pemerintah melibatkan dan memberdayakan masyarakat dalam hal memelihara, meningkatkan dan melindungi kesehatannya. Tujuannya, agar masyarakat sadar, mau, dan mampu secara mandiri ikut aktif dalam meningkatkan status kesehatannya. Namun, ternyata PHBS dan Germas belum sepenuhnya dipahami apalagi diterapkan oleh masyarakat.

Di masa pandemi Covid-19, kampanye PHBS pun kembali digaungkan oleh pemerintah pada masyarakat agar diterapkan untuk memutus mata rantai penyebaran virus. Penerapan PHBS untuk mencegah Covid-19 bukanlah hal yang mudah dilakukan oleh warga masyarakat. Pemerintah pun menghimbau para tokoh masyarakat, baik formal maupun informal, di setiap wilayah untuk berperan aktif dalam mengkampanyekan PHBS pada warga masyarakat untuk mencegah penyebaran Covid-19, dan juga berperan dalam upaya penanggulangan dampak pandemi. Pemerintah melibatkan para tokoh masyarakat karena mereka memiliki kedudukan dan kekuatan sosial untuk mempengaruhi warga masyarakat dalam membentuk suatu perilaku dan memotori gerakan sosial yang bertujuan menanggulangi pandemi.

Penelitian ini membahas perilaku dan peran tokoh masyarakat dalam mencegah penyebaran Covid-19 dengan menampilkan kasus perilaku dan peran para tokoh masyarakat di Desa Jayaraga, Kabupaten Garut, Provinsi Jawa Barat. Penelitian sebelumnya yang pernah dilakukan di wilayah ini, menunjukkan bahwa peran tokoh masyarakat sangat dominan dalam pembentukan dan pelaksanaan perilaku hidup bersih dan sehat (Rosidin, Sumarna, dan Eriyani, 2019). Di dalam konteks pandemi Covid-19, penelitian ini menggambarkan proses pembentukan perilaku pencegahan Covid-19 di kalangan para tokoh masyarakat di desa tersebut dan bagaimana mereka dengan perilakunya tersebut kemudian menjalankan perannya dalam upaya pencegahan Covid-19. 


\section{Kajian Pustaka}

\section{Tokoh masyarakat dan perannya}

Tokoh masyarakat menurut Undang-Undang Republik Indonesia Nomor 8 Tahun 1987 adalah "seseorang yang karena kedudukan sosialnya menerima kehormatan dari masyarakat dan/atau pemerintah" (Pemerintah Republik Indonesia, 1987). Kedudukan tokoh masyarakat diperoleh individu karena pengetahuannya, kebijaksanaan budi pekertinya, dan kesuksesannya dalam menjalani kehidupan di masyarakat. Kebijaksanaan dan pengetahuan yang dimiliki tokoh masyarakat biasanya menjadi panutan bagi orang-orang yang sesuai dengan bidangnya masing-masing. Oleh karena aktifitas, kecakapan dan sifat-sifat yang dimilikinya maka tokoh masyarakat merupakan orang yang dihormati dan disegani (Porawouw, 2016).

Di dalam kaitannya dengan hubungan sosial-budaya, terutama di pedesaan, seorang tokoh masyarakat memiliki pengaruh yang sangat dominan dalam pengambilan kebijakan. Tokoh masyarakat di desa setidaknya dapat dipilah menjadi beberapa jenis elit, diantaranya elit pemerintahan, elit agama, elit ekonomi, elit ormas, elit intelektual, dan elit adat sebagai para stakeholders dengan fungsi dan peranan yang berbeda-beda. Elit pemerintahan merujuk pada kepala desa, kepala dusun, sekretaris desa, dan perangkat desa lainnya. Elit agama merujuk pada tokoh panutan dalam agama seperti kyai, ustadz, pendeta, romo, dan tokoh agama lainnya. Elit ekonomi merujuk pada golongan yang kaya secara ekonomi di desa termasuk para pemilik lahan. Elit Ormas merujuk pada tokoh organisasi kemasyarakatan atau politik yang ada di desa. Elit intelektual merujuk pada individu yang dianggap memiliki kecerdasan, kepandaian, atau karena pendidikannya. Elit adat merujuk pada tokoh yang sangat dihormati dalam tradisi-tradisi atau adat setempat yang masih hidup dalam keseharian masyarakat pedesaan (Porawouw, 2016).

Peran merupakan sesuatu yang melekat pada kedudukan manusia sebagai makhluk sosial, dan diharapkan menjalankan perannya sesuai dengan tuntutan pada kedukukannya tersebut. Di masyarakat, setiap individu memiliki peran sosialnya masing-masing. Efendi (2013) mendefinisikan peran sebagai amanah yang harus diemban dan dipertanggungjawabkan oleh individu secara mutlak. Artinya saat individu diberi peran, maka ia harus menjalankan amanah itu. Hak-hak dan kewajibannya sesuai dengan perannya itu.

Tokoh masyarakat mempunyai peran yang sangat penting. Sebab, pada hakikatnya tokoh masyarakat ialah orang yang mempunyai peranan yang besar dalam suatu kelompok masyarakat dan memiliki kekuasaan yaitu kemampuan mempengaruhi orang atau kelompok lain sesuai dengan keinginan dirinya (Budiardjo, 2008).

Peran tokoh masyarakat antara lain adalah sebagai pengendali sosial, penjaga dan penegak nilai-nilai dan norma-norma yang berlaku dimasyarakat. Selain itu tokoh masyarakat juga berperan dalam memecahkan berbagai permasalahan yang terjadi. Tokoh masyarakat mempunyai kewajiban untuk memberikan dukungan, bimbingan, motivasi serta pengarahan pada masyarakatnya.

Tokoh masyarakat juga berperan sebagai pemberi dukungan. Dukungan tokoh masyarakat dibedakan menjadi dukungan emosional, dukungan penghargaan, dukungan instrumental dan dukungan informatif. Dukungan emosional diindikasikan dengan ungkapan empati, kepedulian dan perhatian. Dukungan penghargaan diindikasikan dengan ungkapan hormat dan pemberian dorongan untuk maju. Dukungan instrumental diindikasikan dengan memberikan bantuan langsung sesuai dengan kebutuhan masyarakat. Dukungan informatif diindikasikan dengan pemberian nasehat, petunjuk, saran dan umpan balik (Akbar, Gani, dan Istiaji 2015).

\section{Perilaku Hidup Bersih dan Sehat (PHBS)}

Perilaku Hidup Bersih dan Sehat (PHBS), merujuk pada perilaku individu atas kesadaran sendiri untuk menolong dirinya sendiri di bidang kesehatan dan berperan aktif dalam kegiatan-kegiatan kesehatan (Kementerian Kesehatan, 2016). Indikator Perilaku Hidup Bersih dan Sehat (PHBS) pada tatanan rumah tangga, adalah: 1) persalinan ditolong oleh tenaga kesehatan, 2) memberi bayi ASI 
eksklusif, 3) menimbang balita setiap bulan, 4) menggunakan air bersih, 5) mencuci tangan dengan air bersih dan sabun, 6) menggunakan jamban sehat, 7) memberantas jentik nyamuk di rumah sekali seminggu, 9) makan buah dan sayur setiap hari, 10) melakukan aktivitas fisik setiap hari, 11) tidak merokok di rumah.

Di dalam konteks pandemi Covid-19, penerapan perilaku hidup bersih dan sehat (PHBS) oleh setiap warga masyarakat disebut sebagai cara yang paling efektif dalam mencegah infeksi dan penyebaran Covid-19 (Karo, 2020; Kementerian Kesehatan, 2016; Tabi' in, 2020; Zukmadini, et al, 2020). Rajin mencuci tangan dengan air bersih dan sabun, makan sayur dan buah, serta aktivitas fisik rutin merupakan perilaku yang dapat mencegah infeksi Covid-19. Oleh karena itu, perilaku ini dikampanyekan secara gencar di masyarakat, bersamaan dengan kampanye penggunaan masker dan menjaga jarak fisik.

\section{Proses pembetukan perilaku}

Green dan Kreuter (1991) menyatakan bahwa perilaku individu, termasuk perilaku kesehatannya, dibangun oleh tiga elemen utama yaitu predisposing factors (faktor pemudah) atau faktor pemicu/anteseden perilaku yaitu faktor yang memberikan alasan atau motivasi pada individu untuk mengadopsi perilaku tersebut, enabling factors atau faktor pemungkin yaitu anteseden perilaku yang memungkinkan motivasi untuk terlaksana, dan reinforcing factors (faktor penguat) atau faktor sesudah perilaku terbentuk yang berperan sebagai reward atau insentif berkelanjutan bagi perilaku dan berkontribusi bagi persistensi atau pengulangannya.

Notoatmodjo (2010) menyebut bahwa perilaku kesehatan adalah respon individu terhadap stimulus atau obyek yang berkaitan dengan sehat sakit, penyakit dan faktor-faktor yang mempengaruhi sehat sakit (kesehatan) seperti lingkungan, makanan, minuman dan pelayanan kesehatan. Artinya, perilaku kesehatan adalah semua aktivitas atau kegiatan seseorang baik yang dapat diamati maupun yang tidak dapat diamati yang berkaitan dengan pemeliharaan dan peningkatan kesehatan.

Ranah perilaku meliputi: Pengetahuan (knowledge), sikap (attitude) dan tindakan atau praktik (practice). Pengetahuan adalah hasil dari tahu, yang terjadi setelah orang melakukan penginderaan terhadap suatu obyek tertentu. Penginderaan terjadi melalui kelima indra manusia, tetapi sebagian besar melalui suatu proses yaitu proses belajar dan membutuhkan suatu bantuan, misalnya bantuan seseorang yang lebih menguasai sesuatu hal, bantuan alat misalnya buku dan sebagainya (Notoatmodjo, 2010).

Sikap adalah respon tertutup individu terhadap stimulus atau obyek tertentu yang melibatkan aspek pendapat dan emosi. Sikap dapat dikatakan sebagai sindrom atau kumpulan gejala dalam merespon stimulus atau obyek. Sikap juga merujuk pada respon individu pada sesuatu hal, dan respon itu melibatkan pikiran, perasaan, perhatian dan gejala kejiwaan yang lain sikap adalah kesiapan atau kesediaan individu untuk bertindak dan bukan merupakan pelaksanaan motif tertentu. Sikap belum merupakan tindakan atau aktifitas akan tetapi baru merupakan predisposisi sebuah perilaku (Notoatmodjo, 2010).

Tindakan, merujuk pada situasi ketika individu atau subyek telah melakukan sesuatu, walaupun tindakan itu masih tergantung pada panduan atau melakukannya secara otomotis maupun dilakukan sekedar rutinitas. Tindakan dapat disebut pula perilaku setelah melalui proses. Biasanya proses itu selalu diawali oleh pengalaman pengalaman indivdudan ditambah oleh faktor faktor di luar dirinya, seperti lingkungan baik fisik maupun nonfisik. Individu kemudian mempersepsikan pengalaman dan faktor lingkungan tersebut. Ia meyakini kedua hal itu sehingga menimbulkan motivasi dan niat untuk bertindak, sehingga terwujudlah sebuah perilaku (Notoatmodjo, 2010).

Pada penelitian ini, pengetahuan para tokoh masyarakat mengenai Covid-19 membentuk sikap mereka pada virus dan upaya pencegahannya. Pengetahuan dan sikap itu mendorong mereka untuk melakukan tindakan. Tindakan mereka yaitu menyebarluaskan informasi mengenai cara pencegahan pada warga masyarakat, menghimbau warga masyarakat untuk mematuhi protokol kesehatan, serta menginisisasi upaya membantu warga masyarakat yang terdampak ekonomi dan sosialnya oleh pandemi. Sikap dan tindakan 
para tokoh masyarakat, sekaligus menggambarkan peran aktif mereka di dalam upaya pencegahan dan penanggulangan pandemi di wilayah mereka.

\section{Metode}

Penelitian ini menggunakan metode kualita tif-deskriptif eksploratoris dengan model studi kasus. Menurut Hermawan (2009) metode kualitatif eksploratoris adalah salah satu jenis penelitian sosial yang bertujuan untuk memberikan penjelasan mengenai konsep atau pola yang digunakan dalam penelitian. Pada penelitian ini hal-hal yang dieksplorasi adalah komponen pembentuk perilaku para tokoh masyarakat yaitu pengetahuan, sikap, dan tindakan mereka terkait pencegahan Covid-19; serta kaitan antara perilaku itu dengan peran mereka sebagai tokoh masyarakat dalam upaya pencegahan Covid-19.

Studi kasus menurut Donsu (2016) adalah salah satu jenis penelitian tentang manusia baik bersifat kelompok, individu, peristiwa maupun organisasi. Pada penelitian ini kasus yang diamati adalah peran para tokoh masyarakat dalam kegiatan yang bertujuan mencegah penyebaran Covid-19.

Populasi dalam penelitian ini adalah tokoh masyarakat yang ada di Desa Jayaraga, Kecamatan Tarogong Kidul Kabupaten Garut. Para calon informan dihubungi melalui telepon dan Whatsapp untuk diberi penjelasan mengenai tujuan penelitian dan ditanya kesediannya berpartisipasi dalam penelitian. Sejumlah 64 tokoh masyarakat berpartisipasi secara sukarela dalam penelitian ini sebagai informan. Mereka adalah elit masyarakat pemerintahan yang terdiri atas para perangkat desa, perangkat RW, dan kader kesehatan dari setiap RW.

Teknik pengumpulan data dilakukan melalui diskusi di grup Whatsapp. Peneliti membuat grup Whatsapp dan mendaftarkan nomor seluruh informan di grup tersebut. Peneliti menyampaikan pertanyaan-pertanyaan di grup Whatsapp, dan dijawab langsung oleh para informan di grup tersebut. Jawaban para informan direkap dan dikategorisasi, kemudian dianalisis mengikuti prinsip dalam analisis data kualitatif.

\section{Hasil dan Pembahasan}

\section{Gambaran Perilaku}

Ranah perilaku meliputi: pengetahuan (knowledge), sikap (attitude) dan tindakan atau praktik (practice) (Notoatmodjo, 2010). Sejalan dengan teori tersebut, perilaku para tokoh masyarakat terhadap Covid-19 dapat dilihat dan ditelusuri dari ranah pengetahuan, sikap, dan tindakan mereka terkait virus tersebut. Berikut ini adalah penjabaran dari ketiga komponen ranah tersebut:

\section{Pengetahuan tentang Covid 19 dan kaitannya dengan PHBS}

Covid-19 adalah jenis virus yang baru saja muncul. Namun, para tokoh masyarakat di Desa Jayaraga sudah dapat mendeskripsikan pengetahuan mereka yang memadai mengenai virus ini. Mereka mendeskripsikan Covid 19 sebagai:

1. Virus yang menyerang sistem pernapasan dan dapat menyebabkan gangguan ringan pada sistem pernapasan, hingga infeksi paru berat yang berdampak pada kematian,

2. Virus yang penyebarannya sangat cepat dan bisa menyebabkan kematian,

3. Virus yang awalnya berasal dari Wuhan China, hampir mirip flu, tapi ada sesak nafasnya dan cepat penyebarannya (penularannya),

4. Penyakit yang menyerang imun tubuh disebabkan oleh virus kelelawar yang bermutasi kepada manusia penyebarannya melalui cipratan batuk atau bersin,

5. Virus disebarkan melalui kontak langsung dengan orang yang terinfeksi.

Deskripsi para tokoh masyarakat tentang Covid 19 menunjukkan bahwa mereka memiliki pengetahuan yang cukup detil mengenai Covid 19. Mereka mendapatkan pengetahuan ini melalui berbagai sumber, seperti media massa, info dari dinas kesehatan yang disebarluaskan di kalangan perangkat dan kader kesehatam, dan juga info yang beredar di media sosial. 
Berkaitan dengan pengetahuan tokoh masyarakat tentang hubungan antara perilaku hidup bersih sehat dengan pencegahan Covid-19 mereka mendeskripsikannya sebagai berikut:

1. Perilaku hidup bersih dan sehat dapat menjaga imunitas tubuh dan bermanfaat untuk pencegahan,

2. Cuci tangan pakai sabun dapat membunuh virus,

3. Perilaku hidup bersih dapat menghindarkan tubuh dari virus corona dan berbagai macam penyakit menular,

4. "Beberesih diri" dengan mencuci tangan pakai sabun dengan bersih di air yang mengalir, selalu membersihkan lantai rumah pakai deisinfektan akan membunuh virus yang sempat menempel di benda dan bertahan hidup selama 8 jam,

5. Corona dapat diatasi dengan menjaga kebersihan diri sendiri dan lingkungan,

6. Perilaku hidup bersih dan sehat insya Allah menghindarkan dari penyakit,

7. PHBS kita dapat mencegah Corona masuk ke tubuh kita,

8. Gaya hidup sehat perlu diterapkan untuk menangkap virus Covid-19 ini,

9. Cuci tangan pakai sabun dengan air yang mengalir adalah cara mencegah Corona,

10. Rajin mencuci tangan dengan sabun dan menutup mulut ketika bersin dan batuk, itu dapat mencegah meluasnya virus Corona dan cuci tangan adalah salah satu dari PHBS,

11. Makan makanan bergizi dan berolah raga, cuci tangan pakai sabun dan air mengalir, memberantas jentik dan tidak merokok dalam rumah itu semua perilaku PHBS, dan apabila dilaksanakan dapat mencegah virus Corona masuk ke dalam tubuh.

Jawaban para tokoh masyarakat mengenai kaitan antara PHBS dengan pencegahan Covid 19 menggambarkan bahwa mereka memiliki pengetahuan memadai mengenai konsep PHBS dan kaitan antara PHBS dan pencegahan Covid 19.

\section{Sikap terhadap Covid-19}

Berdasarkan hasil percakapan di grup Whatsapp, sebagian besar tokoh masyarakat merasa kha- watir pada virus dan dampak pandemi yang ditimbulkan. Kekhawatiran itu disebabkan oleh ukuran virus yang tidak tampak, penularan yang cepat dan dampaknya yang mematikan. Berikut ini salah satu pendapat dari tokoh masyarakat:
"Saya sangat khawatir karena virus ini tidak dapat terlihat oleh kasat mata dan dapat ditularkan melalui benda apapun yang disentuh oleh si penderita." (Diskusi di grup Whatsapp dengan Ibu Suzie, Bag. Kesra Desa, 1 Mei 2020).

Namun, mereka juga menyatakan, meski khawatir, mereka tidak takut karena virus dapat dicegah. Hal ini dituturkan oleh satu tokoh:

"Covid-19 tidak perlu ditakuti. tapi harus tetap waspada dengan menjaga kondisi badan tetap fit. Sebab virus tidak bisa dideteksi menularnya. Menjaga jarak dan selalu menjalankan PHBS, selalu pakai masker bila keluar rumah, cuci tangan sesering mungkin apalagi setelah kita berkegiatan di luar rumah, serta membersihkan lingkungan dengan menyemprotkan disinsfektan (Diskusi di grup Whatsapp dengan Ibu Sutirah, Kader Kesehatan RW 07, 1 Mei 2020).

Penuturan dua tokoh masyarakat itu menggambarkan bahwa mereka memiliki sikap khawatir pada Covid-19, tetapi mereka dapat mengendalikan kekhawatiran dengan pengetahuan mereka tentang cara pencegahannya.

\section{Tindakan Pencegahan Covid-19}

Pengetahuan dan sikap tentang Covid-19 di kalangan para tokoh masyarakat di Desa Jayaraga mendorong mereka untuk melakukan tindakan dalam upaya merespon pandemi. Tindakan yang dilakukan oleh para tokoh masyarakat antara lain menyebarluaskan informasi mengenai Covid-19 dan cara penyebarannya, mengkampanyekan PHBS sebagai upaya pencegahan infeksi, membantu warga kondisi sosial-ekonominya terpuruk akibat pandemi; serta memberikan aneka bentuk dukungan pada warga masyarakat.

\section{Peran tokoh masyarakat}


Pengetahuan, sikap, dan tindakan para tokoh masyarakat dalam konteks pencegahan Covid-19 menggambarkan perilaku mereka. Perilaku itu kemudian mendorong mereka untuk menjalankan perannya di masyarakat dalam upaya pencegahan. Salah satu bentuk peran itu adalah meyediakan dukungan terkait upaya pencegahan dan penanggulangan.

Bentuk dukungan yang diberikan oleh tokoh masyarakat dibedakan menjadi dukungan emosional, dukungan penghargaan, dukungan instrumental dan dukungan informatif. Dukungan emosional mencakup ungkapan empati, kepedulian dan perhatian. Dukungan penghargaan mencakup ungkapan hormat dan dorongan untuk maju. Dukungan instrumental mencakup bantuan langsung sesuai kebutuhan masyarakat. Dukungan informatif mencakup nasehat, petunjuk, saran dan umpan balik (Smet dalam Akbar et al., 2015).

Peran tokoh masyarakat dalam memberikan dukungan informatif tampak dalam upaya mereka menyebarluaskan informasi mengenai pandemi dan pencegahannya. Informasi terlebih dahulu mereka sebar pada anggota keluarga, setelah itu mereka sebar pada tetangga.

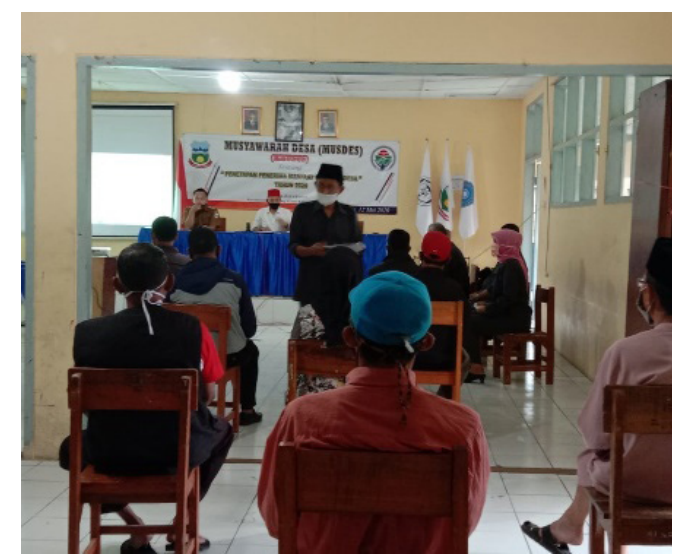

Gambar 1. Kegiatan pemberian informasi mengenai PHBS untuk mencegah Covid-19 oleh tokoh masyarakat pada warga

Selain menyebarkan informasi, mereka juga mempromosikan perilaku hidup bersih dan sehat pada para warga desa (lihat gambar 1). Isi dari promosi itu adalah mensosialisasikan pembatasan sosial dan jaga jarak (social distancing dan physical distancing) pada warga desa; penggunaan masker saat keluar rumah; menghindari kerumunan, membersihkan rumah dengan disinfektan, berjemur diri (moyan), makan makanan sehat dan melakukan olah raga.
Peran tokoh masyarakat dalam memberikan dukungan emosional dan penghargaan tampak dalam ajakan mereka pada warga masyarakat untuk berdoa dan tetap tenang menghadapi situasi pandemi. Mereka percaya, situasi akan membaik atas izin Allah s. Selain mendatangkan dampak kesehatan fisik, pandemi Covid 19 juga mendatangkan dampak sosial di masyarakat. Saat ini banyak warga masyarakat merasakan dampak sosial dari Covid-19. Salah satunya adalah munculnya berbagai masalah sosial seperti pengangguran, kemiskinan, kejahatan dan penyakit kejiwaan. Para tokoh masyarakat mengajak warga untuk saling peduli dan mengerahkan suluruh modal sosial yang ada di desa guna mengatasi persoalan yang muncul akibat pandemi. Penghargaan dan apresiasi para tokoh masyarakat pada kebersamaan warga dalam menghadapi pandemi merupakan bentuk dukungan penghargaan.

Peran para tokoh masyarakat dalam memberikan dukungan instrumental tampak dalam tindakan mereka turut mendistribusikan bantuan masker, sembako dan nasi bungkus dari pemerintah dan donator pada masyarakat (lihat gambar 2).

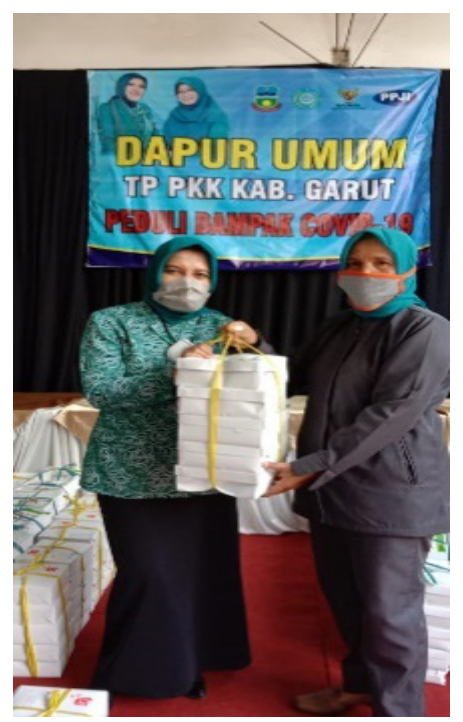

Gambar 2. Kegiatan kader PKK di dapur umum untuk mempersiapkan bantuan makanan bagi warga masyarakat

Para tokoh masyarakat sebagai agen pembaharu sekaligus inisiator di dalam kegiatan pemberdayaan masyarakat. Salah satu bentuk kegiatan pemberdayaan adalah, pembentukan satgas Covid desa yang anggotanya adalah para tokoh masyarakat, dan warga. Tugas mereka adalah melakukan pemeriksaan suhu 
tubuh para warga, dan melakukan penyemprotan disinfektan di lingkungan pemukiman (lihat gambar 3).

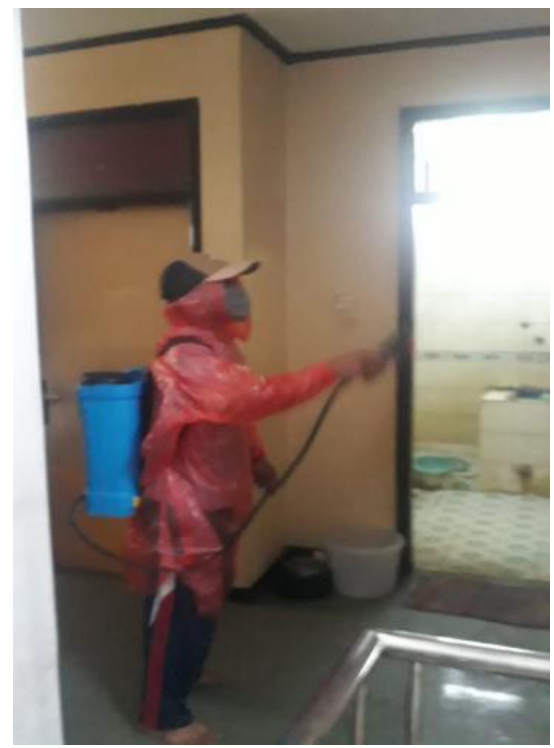

Gambar 3. Penyemprotan disinfektan di perumahan warga

Upaya mengatasi masalah sosial dengan cara pemberdayaan masyarakat ini merupakan hal yang tepat dan dapat berkelanjutan (Pratama, 2019). Pembentukan satgas Covid-19 di tingkat desa ini adalah wujud kegiatan inisiatif pemberdayaan masyarakat yang akan berkelanjutan. Masyarakat berupaya untuk berdikari dan tidak hanya menunggu bantuan dari pemerintah.

\section{Simpulan}

Para tokoh masyarakat di Desa Jayaraga membangun perilaku mereka dalam pencegahan Covid-19 dengan mengakumulasi pengetahuan yang memadai tentang Covid-19 dan cara pencegahannya. Pengetahuan itu membentuk sikap khawatir mereka pada penyebaran virus yang sangat cepat. Namun kekhawatiran itu tidak membuat mereka takut karena mereka mengetahui cara pencegahannya. Pengetahuan dan sikap itu kemudian mendorong mereka untuk bertindak mencegah dan menanggulangi. Mereka memulai tindakan dari lingkup diri sendiri, keluarga dan melebar ke masyarakat. Tindakan yang dilakukan para tokoh masyarakat di atas sekaligus menggambarkan peran aktif mereka sebagai elit pemerintahan di masyarakat dalam konteks pandemi Covid-19. Mereka menjalankan perannya sebagai tokoh masyarakat untuk mempengaruhi dan mengubah perilaku masyarakat, dari yang sebelumnya tidak mengenal dan menjadi mengenal dan menerapkan perilaku hidup bersih dan sehat di kalangan warga masyarakat yang menjadi kunci untuk mencegah penyebaran infeksi Covid-19 di masyarakat.

\section{Daftar Pustaka}

Akbar, M. A., Gani, H. A., dan Istiaji, E. (2015). Dukungan Tokoh Masyarakat dalam Keberlangsungan Desa Siaga di Desa Kenongo Kecamatan Gucialit Kabupaten Lumajang (Community Leaders' Support in the Sustainability of Alert Village in Kenongo Village, Sub District of Gucialit, Lumajang Regency). Pustaka Kesehatan, 3(3), 522-529.

Budiardjo, M. (2008). Dasar-Dasar Ilmu Politik Edisi Revisi. Jakarta: Gramedia.

Donsu, J. D. T. (2016). Metodologi Penelitian Keperawatan. Yogyakarta: Pustaka Baru Press.

Efendi, T. (2013). Peran. Tanggerang Selatan : Lotubooks.

Green, L., dan Kreuter, M. W. (1991). Health Promotion Planning, An Educational and Environmental Approach. California: Mayfield Publishing Co.

Hermawan, A. (2009). Penelitian Bisnis, Paradigma Kuantitatif (Business Research, Quantitative Paradigm). Grasindo, Penerbit PT. Gramedia Widiasarana Jakarta, Indonesia.

Karo, M. B. (2020). Perilaku Hidup Bersih dan Sehat (PHBS) Strategi Pencegahan Penyebaran Virus Covid 19. Prosiding Seminar Nasional Hardiknas, 1-4.

Kementerian Kesehatan. (2016). PHBS. http:// promkes.kemkes.go.id/phbs

Notoatmodjo, S. (2010). Pengantar Pendidikan Kesehatan dan Ilmu Perilaku. Yogyakarta: Andi Offset.

Pemerintah Republik Indonesia. (1987). Undang-Undang Republik Indonesia Nomor 8 Tahun 1987.

Porawouw, R. (2016). Peran Tokoh Masyarakat dalam Meningkatkan Pembangunan. Jurnal Politico, 3(1), 1-17.

Pratama, D. R. (2019). Peran Kewirausahaan Sosial dalam Pemberdayaan Masyarakat: Tiga Cerita dari Kutai Timur. Umbara, 4(2), 115-129.

Primadi, O. (2017). Sosialisasi Gerakan Masyarakat Hidup Sehat (Germas) dalam Temu Blogger Jawa Barat. http://sehatnegeriku.kemkes. 
go.id/wp-content/uploads/2017/04/Sosialisasi-GERMAS-Temu-Blogger-Jawa-barat-2017. ppt

Rosidin, U., Sumarna, U., dan Eriyani, T. (2019). Determinan Pelaksanaan PHBS Rumah Tangga di Desa Jayaraga Tarogong Kidul Kabupaten Garut. Jurnal Keperawatan BSI, 7(1).

Tabi'in, A. (2020). Perilaku Hidup Bersih dan Sehat (PHBS) pada Anak Usia Dini sebagai Upaya Pencegahan Covid 19. JEA (Jurnal Edukasi AUD), 6(1), 58-73.

Zukmadini, A. Y., Karyadi, B., dan Kasrina, K. (2020). Edukasi Perilaku Hidup Bersih dan Sehat (PHBS) dalam Pencegahan Covid-19 kepada Anak-anak di Panti Asuhan. Jurnal Pengabdian Magister Pendidikan IPA, 3(1), 68-76. 